\title{
半径方向の高次モードを考慮した垂直励振を受ける 円筒容器内液面の非線形振動解析*
}

\author{
木 村 康 治*1, 高 原弘 樹*1, 坂 田 勝*2 \\ Effects of Higher Order Radial Modes upon Nonlinear Sloshing \\ in a Circular Cylindrical Tank Subjected to Vertical Excitation
}

\author{
Koji KIMURA, Hiroki TAKAHARA and Masaru SAKATA
}

\begin{abstract}
Parametric vibration of the liquid surface in a partially filled circular cylindrical tank is investigated. The tank is subjected to horizontal, vertical and pitching excitations. Nonlinearity of the liquid surface oscillation is considered in the response analysis of the sloshing motion. The nonlinear and parametric ordinary differential equations, governing the axisymmetric liquid surface oscillation and including the higher order radial modes, are derived by applying Galerkin's method. It is confirmed that the vertical excitation causes the parametric excitation. In addition, it is noted that the pitching excitation also causes the parametric excitation when the pitching axis does not intersect the symmetrical axis of the circular cylindrical tank. The time histories of the liquid surface displacement to the harmonic vertical excitations are calculated in cases where the dominant mode is axisymmetric and where it has nodal radiuses. An experiment was conducted using a model tank. Good agreement was found between the theoretical and experimental results.
\end{abstract}

Key Words : Vibration of Continuous System, Liquid Sloshing, Circular Cylindrical Tank, Nonlinear Vibration, Vertical Excitation, Parametric Vibration, Higher Order Radial Modes

\section{1. 緒言}

容器内液体が外部の励振力と共振し, 液面の振動が 非常に大きくなる現象はスロッシングと呼ばれる、ス ロッシング応答は液面の振幅が大きくなると顕著な非 線形性を示すことが知られており，その動的挙動を明 らかにするためには，液面摇動の非線形性を考慮する ことが不可欠である(1) (4).

液体貨物運搬船やロケット等では, 垂直方向の励振 のため, 内部の液体容器でスロッシングが発生すると, 容器内の動圧に大きな変動が起き, 挙動に悪影響を及 ほすと考えられるので, 垂直方向に励振を受ける容器 内液面のスロッシングの特性を明らかにすることは工 学上重要な課題である.すでに, 垂直方向励振を受け る容器内液面の振動が, パラメトリック振動となるこ とはよく知られており (5), さらに, 最低次モード近傍 の振動モードに着目した非線形パラメトリック振動の 研究も行われている(6)〜(8). しかしながら, 垂直方向の 励振によって, 常に最低次モードがパラメトリック励

\footnotetext{
* 原稿受付 平成 6 年 4 月 21 日.

*1 正員, 東京工業大学工学部（１52 東京都目黒区大岡山 2 $12-1)$.

*2 正員, 拓殖大学工学部 (※193 八王子市館町 815-1).
}

振を引き起こすとは限らないので, 最低次モード近傍 の振動特性だけでは必ずしも十分ではなく，高次のモ ードがパラメトリック共振を起こす場合の振動特性を 明らかにする必要があると考えられる。

著者らはすでに，スロッシング応答の非線形性を考 慮し，ピッチング励振と水平・鉛直方向励振を受ける 場合について液面の非線形応答解析の定式化 ${ }^{(9)}$ を行 い, 節直径を有する任意の振動モードが卓越する場合 について, 半径方向の高次モードの連成を考虑して, 液面摇動を支配する非線形振動方程式を導出するとと もに，調和ピッチング励振を受ける場合に着目して報 告を行っている(10)(11).

本研究では，同様の励振を受ける円筒容器内の液面 摇動を対象にして, 円周方向モードの非線形連成特性 の違い(6)(7)(10) により前報(10)(11) では取扱わなかった任 意の軸対称モードが卓越する場合について, 半径方向 の高次モードの連成を考慮して, 液面摇動を支配する 振動方程式を導出した。調和垂直励振を受ける場合に 着目し,パラメトリック共振によって, 軸対称モード または節直径を有するモードが卓越する両方の場合の 数值計算結果と, モデルタンクを用いた実験結果との 比較・検討を行った結果について報告する，さらに，ピ ッチング励振のみによってパラメトリック共振が生じ 


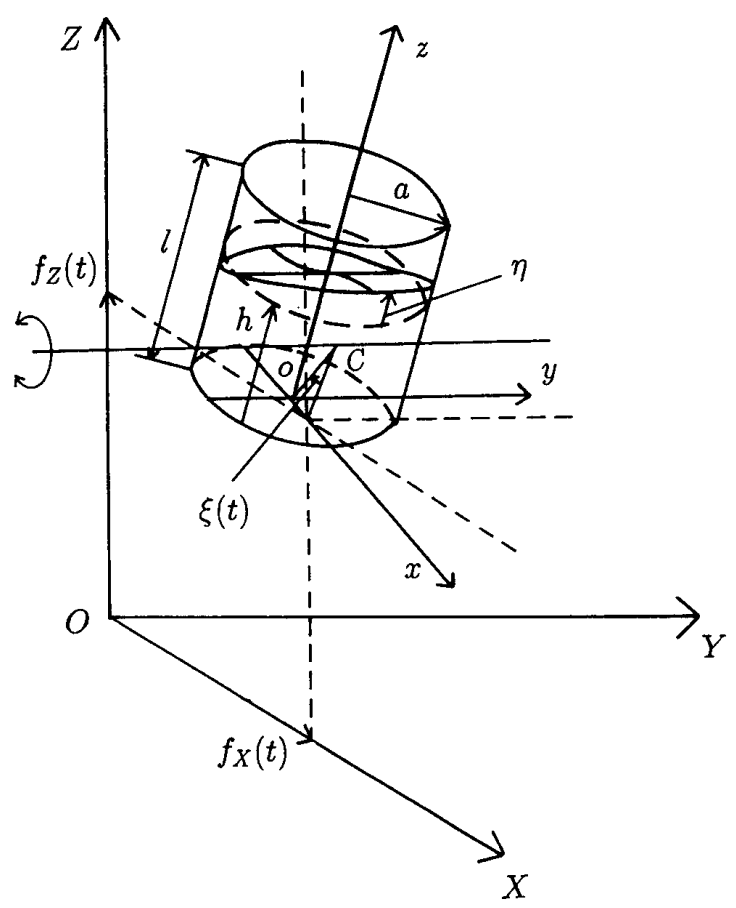

図 1 解析モデル

軸対称モードが卓越する場合があることを指摘し，あ わせて報告を行う。

\section{2. 解 析モテル}

図 1 に剛体円筒容器の解析モデルを示す. O- $X Y Z$ は静止座標系, $0^{-} x y z, 0^{-} r \theta z\left(x\right.$ 軸方向が $\left.\theta=0^{\circ}\right)$ は容 器に固定された移動座標系である. 容器は $X, Z$ 方向 にそれぞれ強制変位 $f_{X}(t), f_{Z}(t)$ を受けると同時に, 座標系 $0^{-} x y z$ 上の一点 $C\left(x_{c}, 0, z_{c}\right)$ (以後, 回転中心と 呼ぶ)を通り $y$ 軸に平行な直線まわりにピッチングに よる角度励振 $\xi(t)$ を受けるものとする。ここで, 剛体 円筒容器の半径を $a$, 高さを $l$, 静止時の液深を $h$, 液 体の密度を $\rho_{f}$ で表し, 重力は $-Z$ 方向(下向き)に働 くものとする。また, 解析では液体は渦なしの非圧縮 性完全流体と仮定する.

\section{3. 理 論 解 析}

卓越するモードが軸対称モードの場合と節直径を有 するモードの場合では, 円周方向モードの非線形連成 が異なる(6)(10) ことから, $3 \cdot 2$ 節以降では, 両者を分け て考察する，なお，節直径を有するモードが卓越する 場合については，前報(10)ですでに報告しているので， 本報では必要に応じて記述することにする。

$3 \cdot 1$ 基礎方程式 液位を $\eta(r, \theta, t)$, 液体の速度 ポテンシャルを $\phi(r, \theta, z, t)$ とすると, 本系の基礎方 程式は変分原理により以下のように導かれる(9).

$$
\begin{aligned}
& \nabla^{2} \phi=\frac{\partial^{2} \phi}{\partial r^{2}}+\frac{\partial \phi}{r \partial r}+\frac{\partial^{2} \phi}{r^{2} \partial \theta^{2}}+\frac{\partial^{2} \phi}{\partial z^{2}}=0 \\
& \left.\frac{\partial \phi}{\partial r}\right|_{r=a}=v_{r},\left.\quad \frac{\partial \phi}{\partial z}\right|_{z=0}=v_{z} \\
& \int_{0}^{2 \pi} \int_{0}^{a} \eta r d r d \theta=0 \\
& \left.\int_{0}^{2 \pi} \int_{0}^{a} P\right|_{z=h+\eta} \delta \eta r d r d \theta=0 \\
& \int_{0}^{2 \pi} \int_{0}^{a}\left\{-\frac{\partial \eta}{\partial t}+\left.\left(\nabla \phi-v_{c}\right)\right|_{z=h+\eta} \cdot \nabla(z-h-\eta)\right\} \\
& \times\left.\delta \phi\right|_{z=h+\eta} r d r d \theta=0
\end{aligned}
$$

ここで, $P$ は静止座標系における圧力であり, 移動座 標系 $o^{-} r \theta z$ の成分を用いて表せば次式のようになる。

$$
\begin{aligned}
& P(r, \theta, z, t)=-\rho_{f}\left[\frac{\partial \phi}{\partial t}-v_{r} \frac{\partial \phi}{\partial r}-v_{\theta} \frac{\partial \phi}{r \partial \theta}-v_{z} \frac{\partial \phi}{\partial z}\right. \\
& \quad+g\left\{-\left(r \cos \theta-x_{c}\right) \sin \xi\right. \\
& \left.\quad+\left(z-z_{c}\right) \cos \xi+f_{z}+z_{c}\right\} \\
& \left.\quad+\frac{1}{2}\left\{\left(\frac{\partial \phi}{\partial r}\right)^{2}+\left(\frac{\partial \phi}{r \partial \theta}\right)^{2}+\left(\frac{\partial \phi}{\partial z}\right)^{2}\right\}+\dot{G}(t)\right]
\end{aligned}
$$

速度ポテンシャル $\phi$ は, 移動座標系 $o^{-} r \theta z$ の成分を 用いて表されている， $g$ は重力加速度， $\dot{G}(t)$ は Euler の運動方程式を積分することで生じる任意の時間の関 数である.また, $v_{r}, v_{\theta}, v_{z}$ は, 容器が静止座標系に対 して有する速度 $\boldsymbol{v}_{c}$ の $r, \theta, z$ 方向成分である ${ }^{(9)}$.

式 (1) は連続条件, 式 (2) は側壁および底面におけ る境界条件, 式 (3) 沙圧縮性の条件, 式 (4), (5) は液面における力学的および運動学的非線形境界条件 である。式(4)，（5）はガレルキン法による計算の便 宜上積分形で記した。

$3 \cdot 2$ 許容関数 スロッシング挙動に着目し, 基 礎方程式の近似解をガレルキン法を用いて求め $3^{(12)}$. 軸対称モードが卓越する場合 (円周方向 0 次・半 径方向 $j$ 次モードが卓越モード $; j \geq 1)$ と節直径を有 するモードが卓越する場合(円周方向 $i$ 次・半径方向 $j$ 次モードが卓越モード： $i, j \geq 1) て ゙$, 円周方向の非線

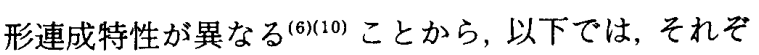
れ別々に解析する。

速度ポテンシャル $\phi$ と液位 $\eta$ の許容関数を, 線形 自由振動解析から得られた固有振動モードによって以 下のように表す. 円周方向 $m$ 次・半径方向 $n$ 次の振動 モードを単に $(m, n)$ モードと表記する。

・軸対称モード $[(0, j)$ モード $]$ が卓越する場合

$$
\begin{aligned}
& \phi(r, \theta, z, t)=A_{0, j} J_{0}\left(\lambda_{0, j} r\right) \frac{\cosh \left(\lambda_{0, j} z\right)}{\cosh \left(\lambda_{0, j} h\right)} \\
& \quad+\sum_{k=1, k \neq j}^{\infty} A_{0, k} J_{0}\left(\lambda_{0, k} r\right) \frac{\cosh \left(\lambda_{0, k} z\right)}{\cosh \left(\lambda_{0, k} h\right)} \\
& \quad+r v_{r}+(z-h) v_{z}+\xi \dot{\xi}\{r(z-h) \cos \theta \\
& \quad+\Pi(r, \theta, z)\} \quad \ldots \ldots \ldots \ldots \ldots \ldots \ldots \ldots \ldots \ldots \ldots \ldots \ldots \ldots \ldots \ldots \ldots \ldots \ldots
\end{aligned}
$$




$$
\eta(r, \theta, t)=C_{0, j} J_{0}\left(\lambda_{0, j} r\right)+\sum_{k^{\prime}=1, k^{\prime} \neq j}^{\infty} C_{0, k^{\prime}} J_{0}\left(\lambda_{0, k^{\prime}} r\right)
$$$$
+r \cos \theta \tan \xi \text {. }
$$

・節直径を有するモード $[(i, j)$ モード $]$ が卓越する場 合(10)

$$
\begin{aligned}
& \phi(r, \theta, z, t)=\left(A_{i, j} \cos i \theta+B_{i, j} \sin i \theta\right) \\
& \times J_{i}\left(\lambda_{i, j} r\right) \frac{\cosh \left(\lambda_{i, j} z\right)}{\cosh \left(\lambda_{i, j} h\right)} \\
& +\sum_{k=1}^{\infty} A_{0, k} J_{0}\left(\lambda_{0, k} r\right) \frac{\cosh \left(\lambda_{0, k} z\right)}{\cosh \left(\lambda_{0, k} h\right)} \\
& +\sum_{k=1}^{\infty}\left(A_{2 i, k} \cos 2 i \theta+B_{2 i, k} \sin 2 i \theta\right) \\
& \times J_{2 i}\left(\lambda_{2 i, k} \gamma\right) \frac{\cosh \left(\lambda_{2 i, k} z\right)}{\cosh \left(\lambda_{2 i, k} h\right)} \\
& +\sum_{k^{\prime}=1, k^{\prime} \neq j}^{\infty}\left(A_{i, k^{\prime}} \cos i \theta+B_{i, k^{\prime}} \sin i \theta\right) \\
& \times J_{i}\left(\lambda_{i, k^{\prime}} r\right) \frac{\cosh \left(\lambda_{i, k^{\prime}} z\right)}{\cosh \left(\lambda_{i, k^{\prime}} h\right)} \\
& +\sum_{k=1}^{\infty}\left(A_{3 i, k} \cos 3 i \theta+B_{3 i, k} \sin 3 i \theta\right) \\
& \times J_{3 i}\left(\lambda_{3 i, k} r\right) \frac{\cosh \left(\lambda_{3 i, k} z\right)}{\cosh \left(\lambda_{3 i, k} h\right)}+r v_{r}+(z-h) v_{z} \\
& +\dot{\xi}\{r(z-h) \cos \theta+\Pi(r, \theta, z)\} \\
& \eta(r, \theta, t)=\left(C_{i, j} \cos i \theta+D_{i, j} \sin i \theta\right) J_{i}\left(\lambda_{i, j} r\right) \\
& +\sum_{k=1}^{\infty} C_{0, k} J_{0}\left(\lambda_{0, k} r\right) \\
& +\sum_{k=1}^{\infty}\left(C_{2 i, k} \cos 2 i \theta+D_{2 i, k} \sin 2 i \theta\right) J_{2 i}\left(\lambda_{2 i, k} r\right) \\
& +\sum_{k^{\prime}=1, k^{\prime} \neq j}^{\infty}\left(C_{i, k^{\prime}} \cos i \theta+D_{i, k^{\prime}} \sin i \theta\right) J_{i}\left(\lambda_{i, k^{\prime}} \gamma\right) \\
& +\sum_{k=1}^{\infty}\left(C_{3 i, k} \cos 3 i \theta+D_{3 i, k} \sin 3 i \theta\right) J_{3 i}\left(\lambda_{3 i, k} r\right) \\
& +r \cos \theta \tan \xi \text {. }
\end{aligned}
$$

ここで, $A_{m, n}(t), B_{m, n}(t), C_{m, n}(t), D_{m, n}(t)$ は一般化 座標, $J_{m}$ は $m$ 次の第 1 種ベッセル関数である. $\lambda_{m, n}$ は円周方向 $m$ 次・半径方向 $n$ 次に対応する固有值で あり，側壁における境界条件式 ( 2 )より定められる $n$ 番めの正根である. 固有值 $\lambda_{m, n}$ と固有振動数 $\omega_{m, n}$ と の間には以下の関係がある.

$$
\omega_{m, n}^{2}=\frac{g \lambda_{m, n}}{a} \tanh \left(\frac{\lambda_{m, n} h}{a}\right)
$$

また， $\Pi$ は境界条件を満たすために必要な項であ る(9).

液面での非線形連成の性質 ${ }^{(2)}$ と卓越するモードの 形状を考慮して, 節直径を有する $(i, j)$ モード ( $i$ 本の 節直径をもつ)が卓越する場合には, 許容関数を軸対 称な $(0, k)$ モード(節直径なし), 節直径を $2 i$ 本もつ $(2 i, k)$ モード, $i$ 本もつ $(i, k)$ モードおよび $3 i$ 本もつ $(3 i, k)$ モ一ドで構成 [式 (9)，(10)]し，一方, 軸対称 な $(0, j)$ モードが卓越する場合には，許容関数を軸対 称な $(0, k)$ モードだけで構成 $[$ 式 $(7)$ ，(8)]した。具
体的には，以下のような理由による，液面での非線形 連成の性質 ${ }^{(2)} に よ り$, 卓越するモードの二乗が見かけ 上の励振力となって連成するモードがある.そのため, 節直径を有する $(i, j)$ モードが卓越する場合には, 連 成するモードは, 見かけ上, 円周方向に $\cos ^{2} i \theta$ また は $\sin ^{2} i \theta$ 状に分布する励振力を受けることになり， 円周方向に変化しない振動モード(軸対称モード)と $\cos 2 i \theta$ または $\sin 2 i \theta$ 状に変化する振動モード（節直 径を $2 i$ 本有するモード) が励起される ${ }^{(10)}$.一方, 軸対 称な $(0, j)$ モードが卓越する場合には, そのモード形 状に三角関数を含まない [式(7)，(8)]ので, 卓越す るモードの二乗と連成するモードにも，軸対称な励振 力だけが作用することになり，節直径を有するモード は励振されず, 円周方向のモード間に連成は生じない と考えたからである。

$3 \cdot 3$ 振動方程式系諸量を容器半径 $a$ と卓越す るモードの固有振動数 $\omega_{0, j}$ または $\omega_{i, j}$ (卓越するモー ドが軸対称か節直径を有するかによる)により無次元 化した後 ${ }^{(9)}$, 卓越するモードに対応した許容関数式 （7），（8）または式（9），(10）を液面における非線形 境界条件式 (4)，（5）に代入して，ガレルキン法を適 用し，液位に関する非線形振動方程式を導く。このと き, 一般化座標と励振のオーダの仮定を行い高次の微 小量を消去する，ここでは，軸対称モードが卓越する 場合に用いたオーダの仮定を示す(節直径を有するモ 一ドが卓越する場合の仮定は省略する(10))。

$$
\left.\begin{array}{ll}
A_{0, j}, \dot{A}_{0, j}, \ddot{A}_{0, j}, C_{0, j}, \dot{C}_{0, j}, \ddot{C}_{0, j} & \sim O\left(\varepsilon^{1 / 3}\right) \\
A_{0, k} \dot{A}_{0, k}, \ddot{A}_{0, k}, C_{0, k}, \dot{C_{0, k}}, \ddot{C}_{0, k}(k \neq j) & \sim O\left(\varepsilon^{2 / 3}\right) \\
f_{X}, \dot{f}_{X}, \ddot{f_{X}}, f_{Z}, \dot{f_{Z}}, \ddot{f_{Z}}, \xi, \dot{\xi}, \ddot{\xi} & \sim O\left(\varepsilon^{3 / 3}\right)
\end{array}\right\}
$$

液位に関する一般化座標について整理すると以下の ような振動方程式系が得られる。

・軸対称モード $[(0, j)$ モード $]$ が卓越する場合

$$
\begin{aligned}
& \ddot{C}_{0, j}+2 \zeta_{0, j} \dot{C}_{0, j}+\left(1+\phi_{0, j} \ddot{f}_{Z}+\psi_{0, j} x_{c} \ddot{\xi}\right) C_{0, j} \\
& \quad=\tilde{P}_{j, j}^{(1)} C_{0, j}^{2}+\tilde{P}_{j, j}^{(2)} \dot{C}_{0, j}^{2}+\tilde{P}_{j, j}^{(3)} C_{0, j}^{3}+\tilde{P}_{j, j}^{(4)} C_{0, j} \dot{C}_{0, j}^{2} \\
& \quad+\sum_{k^{\prime}=1, k^{\prime} \neq j}^{\infty} \tilde{P}_{j, j, k^{\prime}}^{(5)} C_{0, j} C_{0, k^{\prime}} \\
& \quad+\sum_{k^{\prime}=1, k^{\prime} \neq j}^{\infty} \tilde{P}_{j, j, k^{\prime}}^{(6)} \dot{C}_{0, j} \dot{C}_{0, k^{\prime}} \ldots \ldots \ldots \ldots \ldots \ldots(13) \\
& \quad \ddot{C}_{0, k}+2 \zeta_{0, k} \omega_{0, k} \dot{C}_{0, k}+\omega_{0, k}^{2} C_{0, k} \\
& \quad+\tilde{P}_{j, k}^{(1)} C_{0, j}^{2}+\tilde{P}_{j, k}^{(2)} \dot{C}_{0, j}^{2} \\
& \quad+\widetilde{P}_{j, k}^{(3)} C_{0, j}^{3}+\tilde{P}_{j, k}^{(4)} C_{0, j} \dot{C}_{0, j}^{2} \\
& \quad+\sum_{k^{\prime}=1, k^{\prime} \neq j}^{\infty} \tilde{P}_{j, k, k^{\prime}}^{(5)} C_{0, j} C_{0, k^{\prime}} \\
& \quad+\sum_{k^{\prime}=1, k^{\prime} \neq j}^{\infty} \tilde{P}_{j, k, k^{\prime}}^{(6)} \dot{C}_{0, j} \dot{C}_{0, k} \ldots \ldots \ldots \ldots \ldots \ldots \ldots(14) \\
& \quad(k=1,2, \cdots, k \neq j)
\end{aligned}
$$


•節值径を有するモード $[(i, j)$ モード $]$ が卓越する場 合 (一部)

$$
\begin{aligned}
\ddot{C}_{i, j} & +2 \zeta_{i, j} \dot{C}_{i, j}+\left[1+\psi_{i, j} \ddot{f}_{Z}(t)+x_{c} \psi_{i, j} \ddot{\xi}(t)\right] C_{i, j} \\
& +P_{i, j}^{(1)} C_{i, j}^{3}+P_{i, j}^{(2)} C_{i, j} \dot{C}_{i, j}^{2}+P_{i, j}^{(3)} C_{i, j} D_{i, j}^{2} \\
& +P_{i, j}^{(4)} C_{i, j} \dot{D}_{i, j}^{2}+P_{i, j}^{(5)} \dot{C}_{i, j} D_{i, j} \dot{D}_{i, j} \\
& +\sum_{k=1}^{\infty} P_{i, j, 0, k}^{(1)} C_{i, j} C_{0, k}+\sum_{k=1}^{\infty} P_{i, j, 0, k}^{(12)} \dot{C}_{i, j} \dot{C}_{0, k} \\
& +\sum_{k=1}^{\infty} P_{i, j, 2 i, k}^{(11)}\left(C_{i, j} C_{2 i, k}+D_{i, j} D_{2 i, k}\right) \\
& +\sum_{k=1}^{\infty} P_{i, j, 2 i, k}^{(12)}\left(\dot{C}_{i, j} \dot{C}_{2 i, k}+\dot{D}_{i, j} \dot{D}_{2 i, k}\right) \\
& =\left[\sigma_{i, j}^{(P)} \ddot{\xi}_{(}(t)+\sigma_{i, j}^{(H)} \ddot{f}_{X}(t)\right] \delta_{1, i} \ldots \ldots \ldots \ldots \ldots \ldots(15) \\
\ddot{D}_{i, j} & +2 \zeta_{i, j} \dot{D}_{i, j}+\left[1+\psi_{i, j} \ddot{f}_{z}(t)+x_{c} \psi_{i, j} \ddot{\xi}(t)\right] D_{i, j} \\
& +P_{i, j}^{(1)} D_{i, j}^{3}+P_{i, j}^{(2)} D_{i, j} \dot{D}_{i, j}^{2}+P_{i, j}^{(3)} D_{i, j} C_{i, j}^{2} \\
& +P_{i, j}^{(4)} D_{i, j} \dot{C}_{i, j}^{2}+P_{i, j}^{(5)} \dot{D}_{i, j} C_{i, j} \dot{C}_{i, j} \\
& +\sum_{k=1}^{\infty} P_{i, j, 0, k}^{(11)} D_{i, j} C_{0, k}+\sum_{k=1}^{\infty} P_{i, j, 0, k}^{(12)} \dot{D}_{i, j} \dot{C}_{0, k} \\
& +\sum_{k=1}^{\infty} P_{i, j, 2 i, k}^{(11)}\left(C_{i, j} D_{2 i, k}-D_{i, j} C_{2 i, k}\right) \\
& +\sum_{k=1}^{\infty} P_{i, j, 2 i, k}^{(12)}\left(\dot{C}_{i, j} \dot{D}_{2 i, k}-\dot{D}_{i, j} \dot{C}_{2 i, k}\right)=0
\end{aligned}
$$

$\ddot{C}_{0, l}+2 \zeta_{0, \imath} \omega_{0, l} \dot{C}_{0, l}+\omega_{0, l}^{2} C_{0, l}$

$$
=P_{i, j, 0, l}^{(21)}\left(C_{i, j}^{2}+D_{i, j}^{2}\right)+P_{i, j, 0, l}^{(22)}\left(\dot{C}_{i, j}^{2}+\dot{D}_{i, j}^{2}\right)
$$$$
(l=1,2, \cdots)
$$

$\ddot{C}_{2 i, \iota}+2 \zeta_{2 i, \iota} \omega_{2 i, l} \dot{C}_{2 i, l}+\omega_{2 i, \iota}^{2} C_{2 i, \iota}$

$$
=P_{i, j, 2 i, l}^{(21)}\left(C_{i, j}^{2}-D_{i, j}^{2}\right)+P_{i, j, 2 i, l}^{(22)}\left(\dot{C}_{i, j}^{2}-\dot{D}_{i, j}^{2}\right)
$$$$
(l=1,2, \cdots)
$$

$\ddot{D}_{2 i, \iota}+2 \zeta_{2 i, l} \omega_{2 i, l} \dot{D}_{2 i, l}+\omega_{2 i, \iota}^{2} D_{2 i, l}$

$$
\begin{aligned}
& =2\left\{P_{i, j, 2 i, l}^{(21)} C_{i, j} D_{i, j}+P_{i, j, 2 i, l}^{(22)} \dot{C}_{i, j} \dot{D}_{i, j}\right\} \\
& (l=1,2, \cdots) \ldots \ldots \ldots \ldots \ldots \ldots \ldots \ldots \ldots \ldots \ldots \ldots \ldots \ldots \ldots \ldots \ldots \ldots \ldots \ldots \ldots \ldots \ldots \ldots
\end{aligned}
$$

ここで, $\delta_{1, i}$ はクロネッカのデル夕, $\phi_{i, j}=\lambda_{i, j} \tanh$ $\left(\lambda_{i, j} h\right)$ である。軸対称モードが卓越する場合の振動方 程式(13)，(14)中の係数 $\widetilde{P}_{j, k, k^{\prime}}$ 等の詳細は付録に示 す、節直径を有するモードが卓越する場合の振動方程 式(15) 右辺の外力の影響係数 $\sigma_{i, j}^{(P)}, \sigma_{i, j}^{(H)}$ ，および式(15)

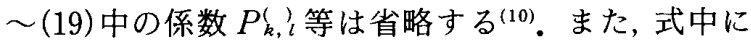
は, エネルギー散逸を等価的に表す線形減衰項を導入 した.

\section{4. 軸対称モードが卓越する場合の 振動方程式の特徵}

節直径を有するモードが卓越する場合の非線形振動 方程式(15)〜 (19)の特性はすでに明らかにしてい る(10)(11) ので，ここでは，軸対称モードが卓越する場 合の非線形振動方程式 (13)，（14）に着目する.

卓越する軸対称モードに対して, 垂直励振がパラメ
トリック振動を起こすことが確認できる(5).さらに， ピッチング励振も式(13)より, 垂直励振とともに $x_{c} \psi_{0, j}$ 芒の形でパラメトリック励振として卓越するモ ードに作用していることがわかる。一方, 垂直励振 $\left(\ddot{f}_{Z}\right)$, 水平励振 $\left(\ddot{f}_{X}\right)$, ピッチング励振 $(\ddot{\xi})$ のいずれも, 軸対称モードを直接励振できない.このため, 液面が 完全に静止した状態では，これらの励振を加えても液 面摇動は生じないが, 初期擾乱がある場合には, 垂直 励振または $x_{c} \neq 0$ の場合のピッチング励振を加える とパラメトリック共振によって大きな液面摇動が生じ ると考えられる。

\section{5. 実験}

$5 \cdot 1$ 垂直励振 垂直励振用の実験装置のブロッ ク線図を図 2(a) に示す. 低周波発信器で正弦波 $f_{Z}(t)$ $=f_{z 0} \sin \omega t$ を発生させ, 油圧加振器に入力し, 円筒 容器に鉛直方向励振を加えた. 静止状態から励振を開 始すると液面摇動が成長しにくいので, 励振開始は, 測定時の励振振幅より大きい振幅で加振し，液面摇動 がパラメトリック共振で成長した後, 励振振幅を測定

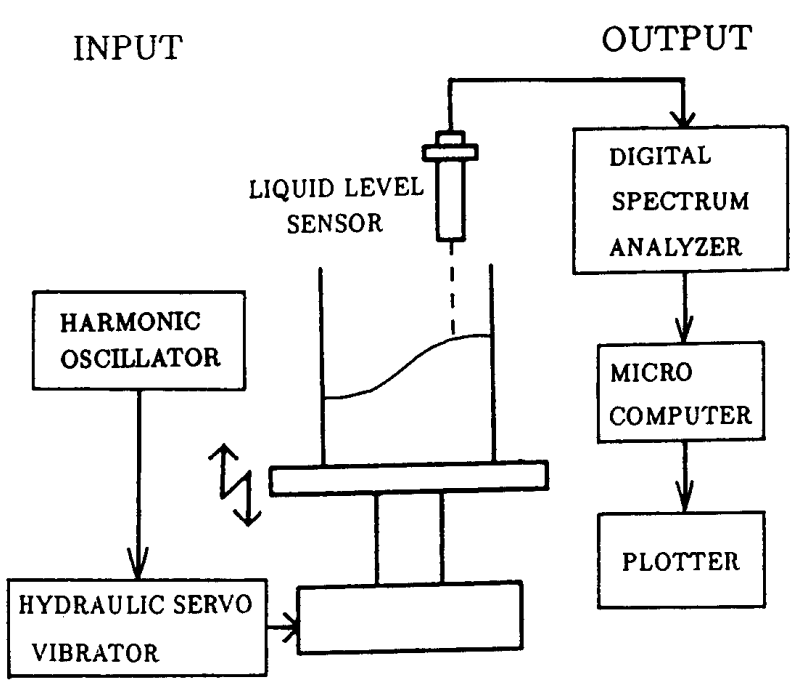

(a ) 垂直励振

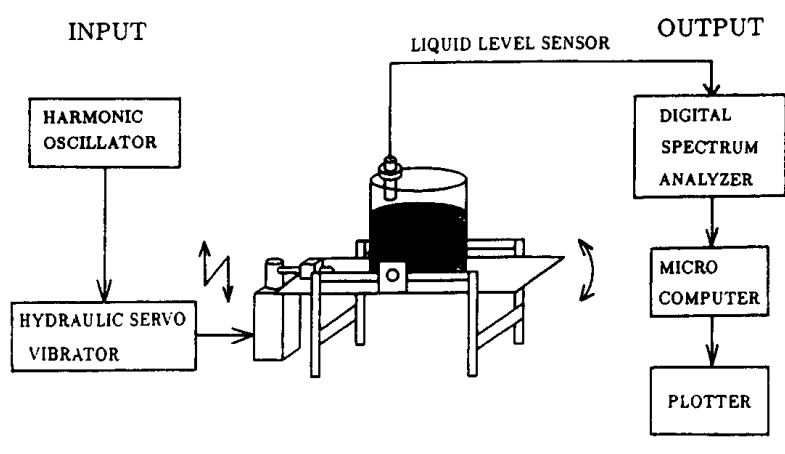

(b) ピッチング励振

図 2 実験装置概略図 
時の大きさに調整(振幅を小さく)し，液面摇動が定常 に達したことを確認した後, 超音波式変位計を用いて 液位を測定した。模型円筒容器はアクリル製で内半径 $140 \mathrm{~mm}$, 高さ $300 \mathrm{~mm}$ である。

$5 \cdot 2$ ピッチング励振 ピッチング励振用の実験 装置のブロック線図を図 2(b)に示す。低周波発信器 で正弦波 $\xi(t)=\xi_{0} \sin \omega t$ を発生させ, 油圧加振器に 入力し, 摇動台の先端に鉛直方向励振を加えることに よって円筒容器にピッチング励振を与えた.ピッチン グ励振を加える場合には，垂直励振時に用いた励振振 幅の調整は行っていない. 円筒容器や変位計は垂直励 振と同じものを用いた。

\section{6. 結果および考察}

6.1 垂直励振図 $3 \sim 9 k$, 調和垂直励振 $\left(f_{z}=\right.$ $\left.f_{z 0} \sin \omega t\right)$ に対する腹の位置での液位の定常応答波形 を示す. 各図の横軸の時間は定常状態に達した後の経 過時間である. 液深は, いずれも円筒容器の半径で無 次元化した値(以下も同様)で $h=1.0$ である. パラメト リック振動により軸対称モードが成長する場合(図 3 , 4) と節直径を有するモードが成長する場合 (図 5～9) について示す、いずれも上段は解析結果, 下段は実験 結果を表す。なお，計算では，適当な初期擾乱を与
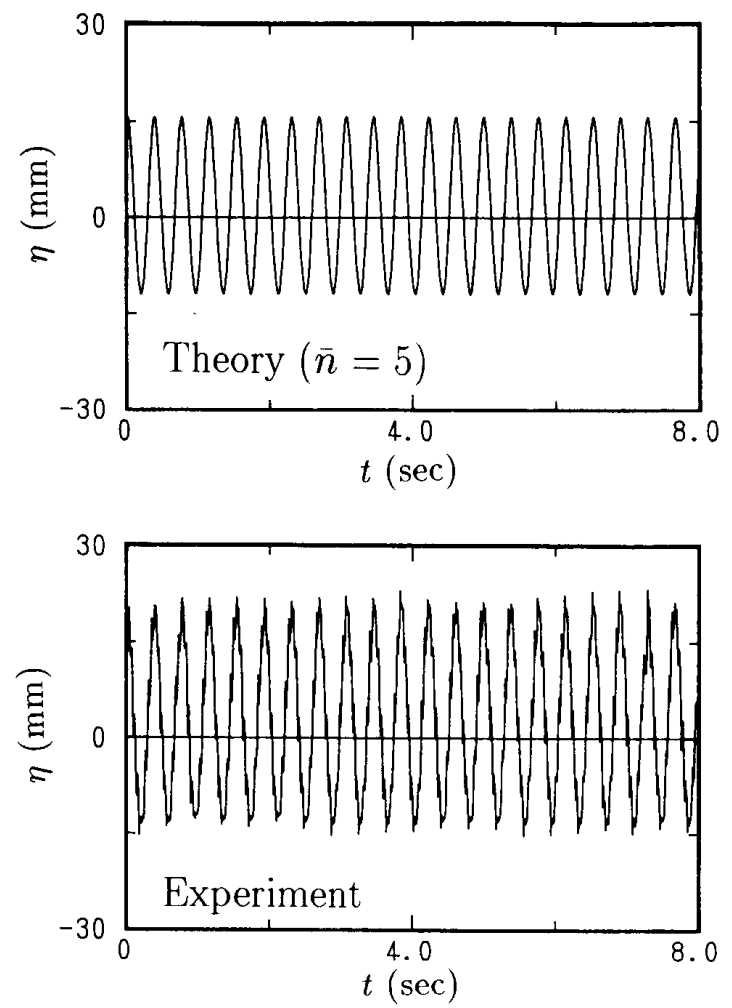

図 3 中心部での液位の時刻歴応答 $[(0,1)$ モード卓越 $]$ $\left(h=1.0, \zeta_{m, n}=0.004, \omega=2 \omega_{0,1}, f_{z 0}=0.32 \mathrm{~mm}\right)$
え,さらに, 振動方程式[軸対称モードが卓越する場合 は式(13)，(14)，節直径を有するモードが卓越する場 合は式(15)〜 (19)］中の等価粘性隇衰比は, すべての モードに対して $\zeta_{m, n}=0.004$ 〔液面摇動の基本モード $[(1,1) モ ー ト ゙ ］ の$ 減衰自由振動波形から算定]を用い た. また, 半径方向の高次モードを無限大までとるこ とができないので, 収束を確認し，考慮する次数を $\bar{n}$ 次までとした。

6・1・1 軸対称モードが卓越する場合 図 3 は, 調和垂直励振の振動数が $(0,1)$ モードの固有振動数 $\left(\omega_{0,1}^{*}=2.61 \mathrm{~Hz}\right.$, 上添字 * は有次元量を表す, 以下同 椂) 22 倍 $\left(\omega=2 \omega_{0,1}\right)$, 励振振幅が $f_{Z 0}=0.32 \mathrm{~mm}$, 半 径方向 5 次モードまで考慮 $(\bar{n}=5)$ した場合, 図 4 は, 励振振動数が $(0,2)$ モードの固有振動数 $\left(\omega_{0,2}^{*}=3.53\right.$ $\mathrm{Hz})$ の 2 倍 $\left(\omega=2 \omega_{0,2}\right)$, 励振振幅が $f_{z 0}=0.21 \mathrm{~mm}$, 半 径方向 13 次モードまで考慮 $(\bar{n}=13)$ した場合の容器 中央部での夜位応答である. 両図とも計算結果と実験 結果は一致しており，パラメトリック共振によりそれ ぞれ $(0,1),(0,2)$ モードが成長し，液面摇動が大きく なることがわかる．また，正側の振幅が負側の振幅よ り大きくなる非線形性の影響がよく現れている。

6・1・2 節直径を有するモードが卓越する場合 図 5,6 は, 励振振動数が $(1,1)$ モドの固有振動数
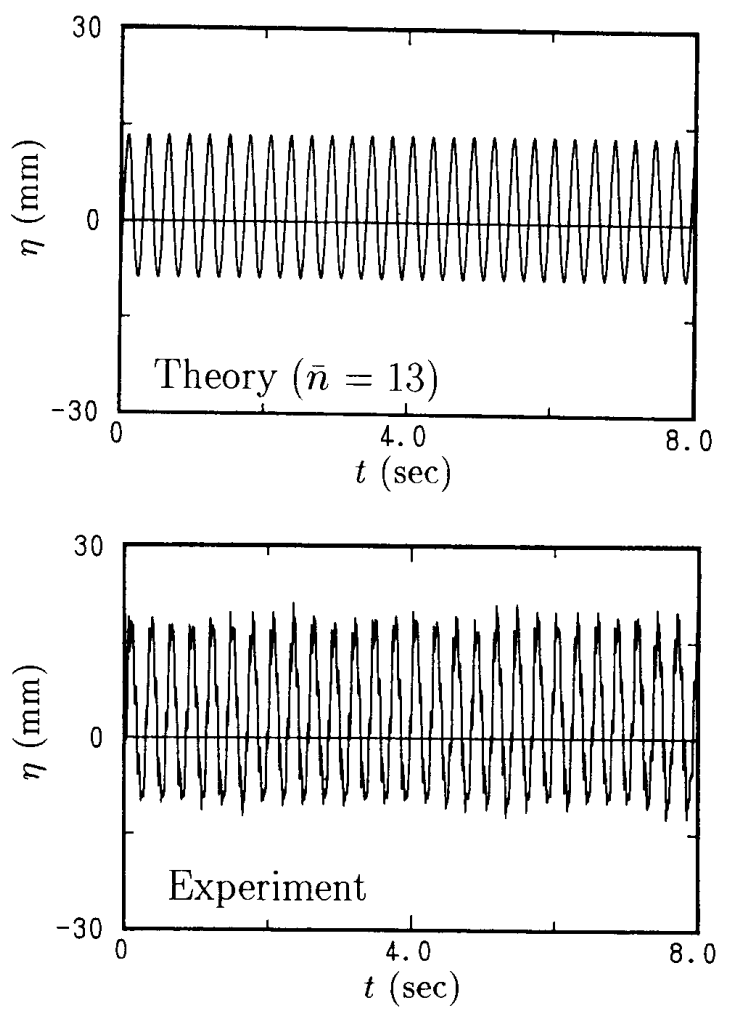

図 4 中心部での液位の時刻歴応答 $[(0,2)$ モード卓越 $]$ $\left(h=1.0, \zeta_{m, n}=0.004, \omega=2 \omega_{0,2}, f_{Z 0}=0.21 \mathrm{~mm}\right)$ 
$\left(\omega_{1,1}^{*}=1.76 \mathrm{~Hz}\right)$ の 2 倍 $\left(\omega=2 \omega_{1,1}\right)$, 励振振幅が $f_{z 0}=$ $0.52 \mathrm{~mm}$, 半径方向 5 次モードまで考慮 $(\bar{n}=5)$ した場 合の側壁近傍および容器中央部付近 $(r=0.1$, 半径 $r$ は容器半径で無次元化, 以下同様)での液位応答であ る.側壁近傍での液位応答（図 5 ) は, 計算結果と実験 結果はよく一致しており，パラメトリック共振により $(1,1)$ モードが成長し，液面摇動が大きくなることが わかる。また，パラメトリック共振によって大きくな る $(1,1)$ モードの節近傍の容器中央部付近の液面摇動 (図 6 )に, 図 5 に現れている $(1,1)$ モードの 2 倍の振 動数の液面摇動が現れているのは，前報 ${ }^{(10)}$ で報告し たようにこの液深 $(h=1.0)$ では，(1, 1) モ一ドが大き く成長すると非線形連成によって, $(1,1)$ モードの 2 倍の振動数で振動する軸対称の $(0,2)$ モードも大きく なるからである，図6の計算結果, 実験結果は振幅に は少し差があるが，ともにこの非線形連成の影響をよ く示している，振幅に現れた差のおもな原因は，数値 計算においてすべてのモードに対して同じ隇衰比を仮 定したため, 計算結果と実験結果では液面摇動に対す る高次モードからの影響に差が生じたことにあると考 えられる。

図 7 は, 調和垂直励振の振動数が $(1,2)$ モードの固
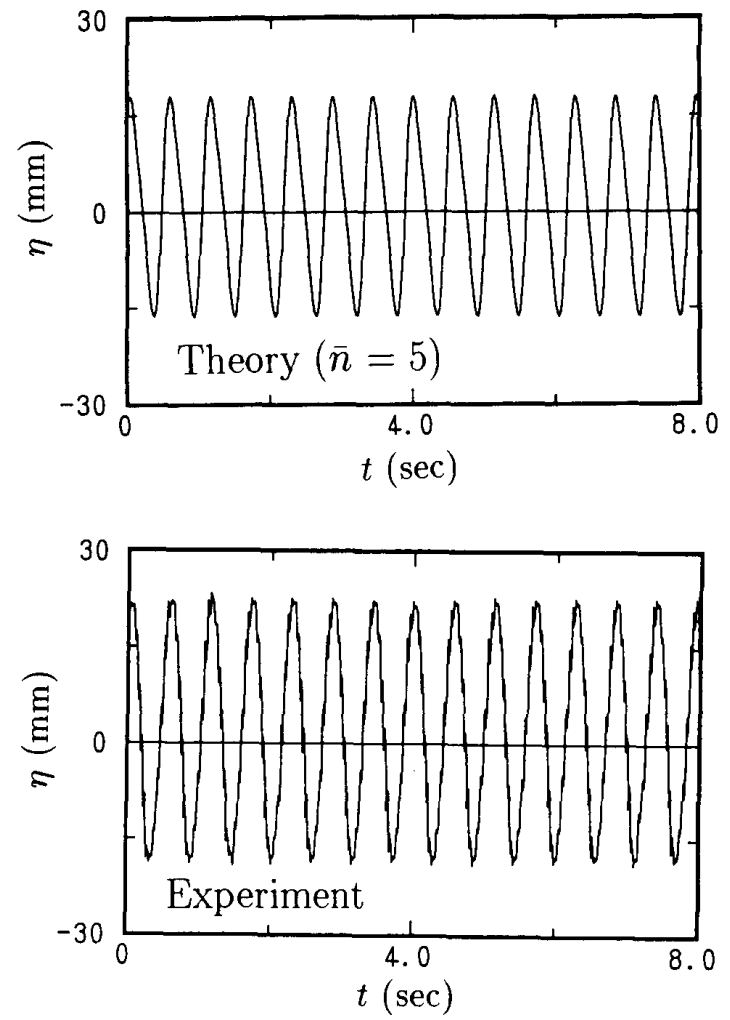

図 5 側壁近傍で液位の時刻歴応答 $[(1,1)$ モード卓越 $]$ $\left(h=1.0, \zeta_{m, n}=0.004, \omega=2 \omega_{1,1}, f_{z 0}=0.52 \mathrm{~mm}\right)$
有振動数 $\left(\omega_{1,2}^{*}=3.08 \mathrm{~Hz}\right)$ の 2 倍 $\left(\omega=2 \omega_{1,2}\right)$, 励振振幅 が $f_{z 0}=0.39 \mathrm{~mm}$, 半径方向 7 次モードまで考慮 $(\bar{n}=$ 7)した場合の側壁と中心の中間部 $(r=0.35) て ゙ の$, 図 8 は, 励振振動数が $(2,1)$ モードの固有振動数 $\left(\omega_{2,1}^{*}=\right.$ $2.32 \mathrm{~Hz})$ の 2 倍 $\left(\omega=2 \omega_{2,1}\right)$, 励振振幅 が $f_{z 0}=0.50$ $\mathrm{mm}$, 半径方向 7 次モードまで考慮 $(\bar{n}=7)$ した場合の 側壁と中心の中間部 $(r=0.50) て ゙ の$, 図 9 は, 励振振動 数が $(2,2)$ モードの固有振動数 $\left(\omega_{2,2}^{*}=3.45 \mathrm{~Hz}\right)$ の 2 倍 $\left(\omega=2 \omega_{2,2}\right)$, 励振振幅が $f_{z 0}=0.35 \mathrm{~mm}$, 半径方向 11 次モードまで考慮 $(\bar{n}=11)$ した場合の側壁と中心の中 間部 $(r=0.46)$ での液位応答である. 図 $8[(2,1)$ モード が卓越する場合にには高次モードからの影響に若干差 があるが, 各図とも計算結果と実験結果は一致してい る。また，パラメトリック共振によりそれぞれ $(1,2)$ ， $(2,1),(2,2)$ モードが成長し，液面摇動が大きくなる ことがわかる. 図 $7[(1,2)$ モードが卓越する場合 $]$, 図 $9[(2,2)$ モードが卓越する場合]には，正側の振幅が負 側の振幅より大きくなる非線形性の影響がよく現れて いる.

6・2 ピッチング励振 4 章で述べたように, ピ ッチング励振のみを加えた場合にも，その回転中心位 置が $x_{c} \neq 0$ の場合には, パラメトリック共振が生じる
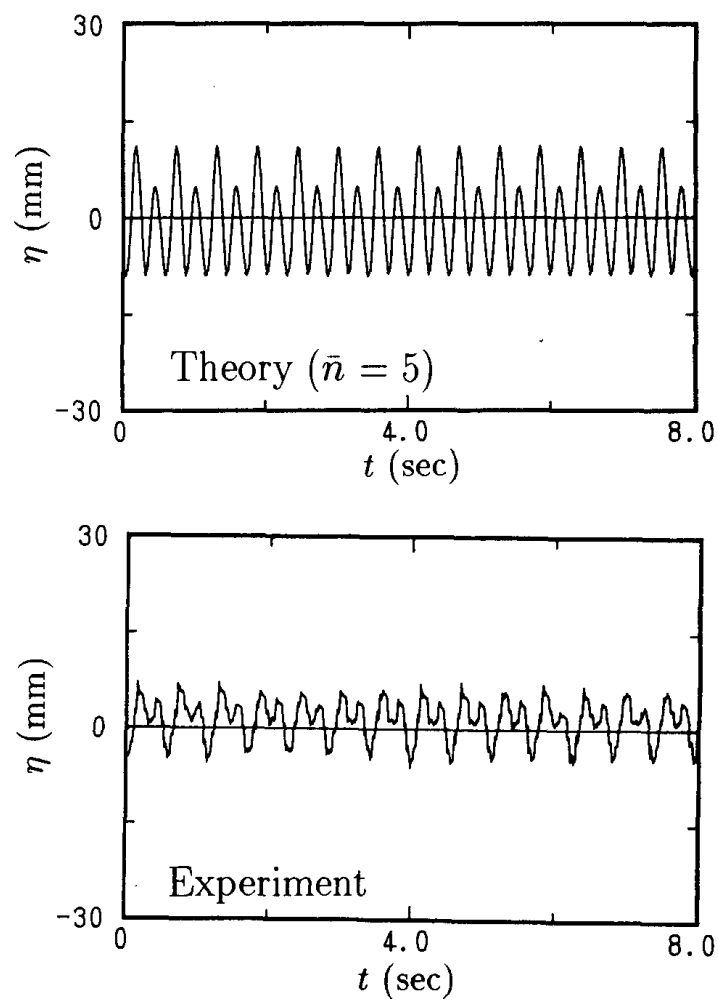

図 6 中心部付近 $(r=0.1)$ での液位の時刻歴応答 $[(1,1)$ モード卓越 $]$ $\left(h=1.0, \zeta_{m, n}=0.004, \omega=2 \omega_{1,1}, f_{z 0}=0.52 \mathrm{~mm}\right)$ 

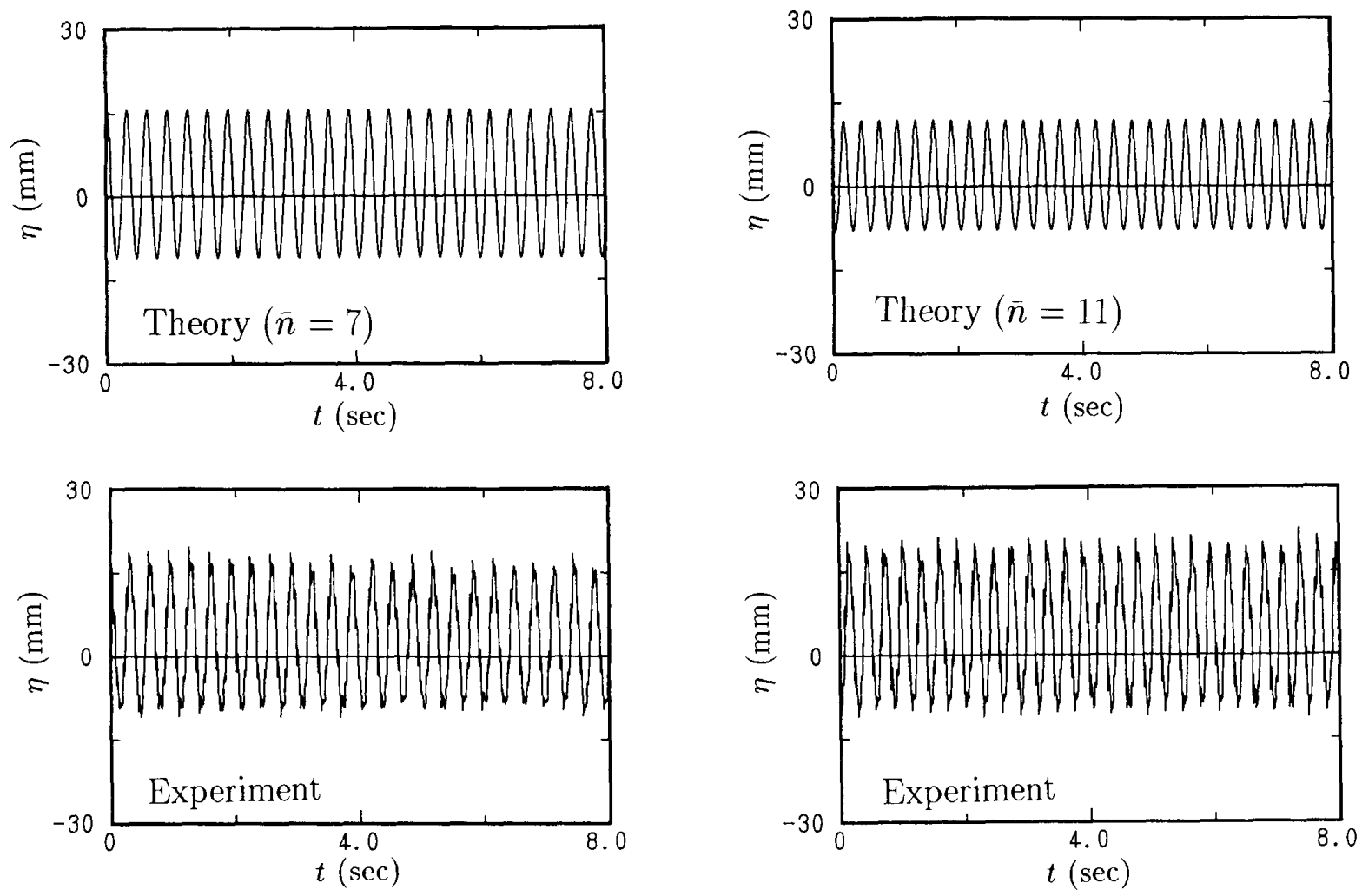

図 7 側壁と中心の中間部 $(r=0.35)$ での液位の 時刻歴応答 $[(1,2)$ モード卓越] $\left(h=1.0, \zeta_{m, n}=0.004, \omega=2 \omega_{1,2}, f_{z 0}=0.39 \mathrm{~mm}\right)$

図 9 側壁と中心の中間部 $(r=0.46)$ での液位の 時刻歷応答 $[(2,2)$ モード卓越]

( $\left.h=1.0, \zeta_{m, n}=0.004, \omega=2 \omega_{2,2}, f_{Z 0}=0.35 \mathrm{~mm}\right)$
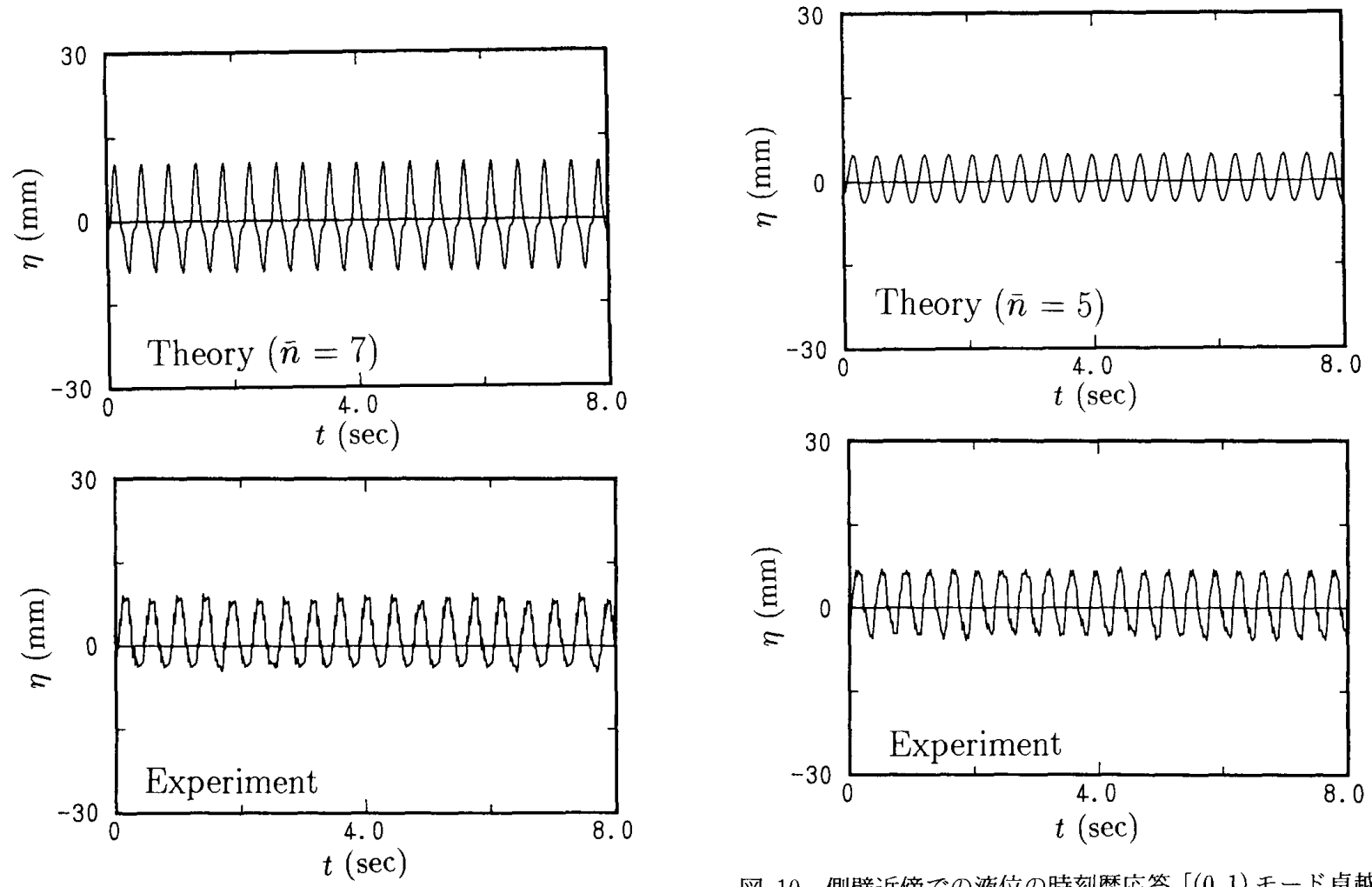

図 8 側壁と中心の中間部 $(r=0.50)$ での液位の 時刻歴応答 $[(2,1)$ モード卓越 $]$

$\left(h=1.0, \zeta_{m, n}=0.004, \omega=2 \omega_{2,1}, f_{z 0}=0.50 \mathrm{~mm}\right)$

図 10 側壁近傍での液位の時刻歴応答 $[(0,1)$ モード卓越 $]$ (ピッチング励振によるパラメトリック共振) $\left(h=1.0,\left(x_{c}, z_{c}\right)=(0.743,0), \zeta_{m, n}=0.004\right.$, $\left.\omega=2 \omega_{0,1}, \xi_{0}=0.12^{\circ}\right)$ 
ことを確認するために，図 10 に,ピッチングの回転中 心位置を $\left(x_{c}, z_{c}\right)=(0.743,0)$ とした場合の調和ピッチ ング励振 $\left[\xi(t)=\xi_{0} \sin \omega t\right]$ に対する側壁近傍での腹の 位置での液位の定常応答を示す．横軸の時間は定常状 態に達した後の経過時間である．液深は $h=1.0$, 励振 振動数は $(0,1)$ モードの固有振動数 $\left(\omega_{0,1}^{*}=2.61 \mathrm{~Hz}\right)$ の 2 倍 $\left(\omega=2 \omega_{0,1}\right)$, 励振の角度振幅は $\xi_{0}=0.12^{\circ}$, 半径方

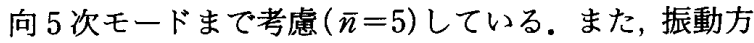
程式(13)，(14)中の等価粘性減衰比は，すべてのモー ドに対して $\zeta_{m, n}=0.004$ とした，上段の計算結果と下 段の実験結果は一致しており， $x_{c} \neq 0$ の場合，ピッチ ング励振のみを加えるだけでも, パラメトリック共振 を起こし，液面摇動が励起できることがわかる.

\section{7. 結 枯}

剛体円筒容器がピッチング励振と水平・垂直方向励 振を同時に受ける場合について，前報(9)で定式化した 非線形応答解析の基礎方程式に基づいて，ガレルキン 法を用いて任意の軸対称モードが卓越する場合につい て，液面摇動を支配する振動方程式を導出した。この とき, 半径方向の高次モードの連成を考慮している. 導出した振動方程式から，垂直励振がパラメトリック 振動を起こすことを確認した。さらに，モデルタンク を用いて実験を行い，計算結果と実験結果を比較・検 討することによって，以下の結論を得た。

（1）垂直方向励振を受ける場合において，軸対称 な $(0,1)$ および $(0,2)$ モードが卓越する場合について， 計算結果と実験結果はよく一致することを示し, 半径 方向の高次モードを考慮する本解析法の有効性を明ら かにした。

（2）垂直方向励振を受ける場合において，節直径 を有する $(1,1),(1,2),(2,1)$ および $(2,2)$ モードが卓 越する場合について, 計算結果と実験結果はよく一致 することを示し, 前報(10) で示した半径方向の高次モ ードを考慮する解析法が垂直励振を受ける場合におい ても有効であることを明らかにした。

（3）ピッチング励振のみが作用する場合でも，パ ラメトリック振動により軸対称モードが成長する場合 があることを示し, 実験によって確認した。

\section{付 録}

式(13)，(14)中の係数 $\tilde{P}_{j k k^{\prime}}$ 等は以下のとおりであ る.

$$
\tilde{P}_{k, l}^{(1)}=\psi_{0,} \widetilde{K}_{k, k, l}^{(z)}-\frac{1}{\psi_{0, k}} \tilde{H}_{k, l}^{(6)}
$$

$$
\begin{aligned}
& \tilde{P}_{k, l}^{(2)}=-\psi_{0, l} \tilde{H}_{k, l}^{(1)}+\frac{1}{\psi_{0, k}} \tilde{H}_{k, l}^{(6)} \\
& \tilde{P}_{k, l}^{(3)}=\psi_{0, l} \tilde{H}_{k, l}^{(2)}+\tilde{H}_{k, l}^{(6)} \widetilde{K}_{k, k, l}^{(z)} \\
& -\frac{1}{\psi_{0, k}} \tilde{H}_{k, l}^{(7)}+\sum_{i \neq k} \tilde{H}_{k, l, i}^{(9)} \tilde{K}_{k, k, i}^{(z)} \\
& \tilde{P}_{k, l}^{(4)}=\psi_{0, l} \tilde{H}_{k, l}^{(3)}-\tilde{H}_{k, l}^{(6)} \tilde{H}_{k, k}^{(1)}+\tilde{H}_{k, l}^{(6)} \tilde{H}_{k, k}^{(10)} \\
& +\frac{2}{\psi_{0, k}} \tilde{H}_{k, l}^{(7)}+\sum_{i \neq k}\left\{H_{k, i}^{(10)}-H_{k, i}^{(1)}\right\} H_{k, l, i}^{(9)} \\
& \tilde{P}_{k, l, i}^{(5)}=\phi_{0, l} \tilde{H}_{k, l, i}^{(4)}-\frac{1}{\psi_{0, k}}\left\{\tilde{H}_{k, l, i}^{(8)}+\tilde{H}_{k, l, i}^{(9)}\right\} \\
& \tilde{P}_{k, l, i}^{(6)}=\psi_{0, l} \tilde{H}_{k, l, i}^{(5)}+\frac{1}{\psi_{0, k}} \tilde{H}_{k, l, i}^{(8)}+\frac{1}{\psi_{0, i}} \tilde{H}_{k, l, i}^{(9)} \\
& (k, l, i=1,2,3, \cdots)
\end{aligned}
$$

ここで

$$
\begin{aligned}
& \tilde{H}_{k, l}^{(1)}=\frac{1}{2 \psi_{0, k}^{2}}\left(\tilde{K}_{k, k, l}^{(r)}+\psi_{0, k}^{2} \tilde{K}_{k, k, l}^{(z)}\right) \\
& \tilde{H}_{k, l}^{(2)}=\frac{\lambda_{0, k}^{2}}{2 \psi_{0, k}} \tilde{K}_{k, k, k, l}^{(z)}-\sum_{i=1}^{\infty} \psi_{0, i} \tilde{K}_{k, i, l}^{(z)} \tilde{K}_{k, k, i}^{(z)} \\
& \tilde{H}_{k, l}^{(3)}=-\frac{1}{\phi_{0, k}}\left(\tilde{K}_{k, k, k, l}^{(r)}+\lambda_{0, k}^{2} \tilde{K}_{k, k, k, l}^{(z)}\right) \\
& +\sum_{i=1}^{\infty}\left\{\frac{\psi_{0, i}}{2 \psi_{0, k}^{2}} \tilde{K}_{k, i, l}^{(z)}\left(\tilde{K}_{k, k, i}^{(r)}+\psi_{0, k}^{2} \tilde{K}_{k, k, i}^{(z)}\right)\right. \\
& -\frac{1}{\psi_{0, k}^{2} \psi_{0, i}}\left(\tilde{K}_{k, i, l}^{(r)}+\psi_{0, k} \psi_{0, i} \tilde{K}_{k, i, l}^{(z)}\right) \\
& \left.\times\left(\tilde{K}_{k, k, i}^{(r)}-\lambda_{0, k}^{2} \tilde{K}_{k, k, i}^{(z)}\right)\right\} \\
& \tilde{H}_{k, l, i}^{(4)}=\left(1+\frac{\phi_{0, i}}{\psi_{0, k}}\right) \tilde{K}_{k, i, \iota}^{(z)} \\
& \tilde{H}_{k, l, i}^{(5)}=-\frac{1}{\psi_{0, k} \psi_{0, i}}\left(\widetilde{K}_{k, i, l}^{(r)}+\psi_{0, k} \psi_{0, i} \widetilde{K}_{k, i, l}^{(z)}\right) \\
& \tilde{H}_{k, l}^{(6)}=\lambda_{0, k}^{2} \tilde{K}_{k, k, l}^{(z)}-\tilde{K}_{k, k, l}^{(r)} \\
& \tilde{H}_{k, l}^{(\gamma)}=-\left(\phi_{0, k}+\psi_{0, l}\right) \tilde{K}_{k, k, k, l}^{(r)} \\
& +\lambda_{0, k}^{2}\left(\frac{1}{2} \psi_{0, k}+\psi_{0, l}\right) \tilde{K}_{k, k, k, l}^{(2)} \\
& +\sum_{i=1}^{\infty} \psi_{0, \ell}\left(\tilde{K}_{k, k, i}^{(r)}-\lambda_{0, k}^{2} \tilde{K}_{k, k, i}^{(z)}\right) \tilde{K}_{k, i, l}^{(z)} \\
& \tilde{H}_{k, l, i}^{(8)}=\lambda_{0, k}^{2} \tilde{K}_{k, i, l}^{(z)}-\tilde{K}_{k, i, l}^{(r)} \\
& \tilde{H}_{k, l, i}^{(9)}=\lambda_{0, i}^{2} \tilde{K}_{k, i, l}^{(z)}-\tilde{K}_{k, i, l}^{(r)} \\
& \tilde{H}_{k, l}^{(10)}=\frac{1}{\psi_{0, k} \psi_{0, l}}\left(\tilde{K}_{k, k, l}^{(r)}-\lambda_{0, k}^{2} \tilde{K}_{k, k, l}^{(z)}\right) \\
& (i, k=1,2, \cdots)
\end{aligned}
$$

さらに,

$$
\begin{aligned}
& \tilde{K}_{a, b, c, d}^{(r)}=\int_{0}^{1} r \frac{d J_{0}\left(\lambda_{0, a} r\right)}{d r} \frac{d J_{0}\left(\lambda_{0, b} r\right)}{d r} \\
& \quad \times J_{0}\left(\lambda_{0, c} r\right) J_{0}\left(\lambda_{0, d} r\right) d r / \tilde{I}_{0, d} \\
& \tilde{K}_{a, b, c, d}^{(z)}=\int_{0}^{1} r J_{0}\left(\lambda_{0, a} r\right) J_{0}\left(\lambda_{0, b} r\right) J_{0}\left(\lambda_{0, c} r\right) \\
& \quad \times J_{0}\left(\lambda_{0, d} r\right) d r / \tilde{I}_{0, d} \\
& \tilde{K}_{a, b, c}^{(r)}=\int_{0}^{1} r \frac{d J_{0}\left(\lambda_{0, a} r\right)}{d r} \frac{d J_{0}\left(\lambda_{0, b} r\right)}{d r} \\
& \quad \times J_{0}\left(\lambda_{0, c} r\right) d r / \tilde{I}_{0, c}
\end{aligned}
$$




$$
\begin{aligned}
& \tilde{K}_{a, b, c}^{(z)}=\int_{0}^{1} r J_{0}\left(\lambda_{0, a} r\right) J_{0}\left(\lambda_{0, b} r\right) J_{0}\left(\lambda_{0, c} r\right) d r / \tilde{I}_{0, c} \\
& \tilde{I}_{0, a}=\int_{0}^{1} r\left\{J_{0}\left(\lambda_{0, a} r\right)\right\}^{2} d r
\end{aligned}
$$

である。

\section{文献}

(1) Abramson, H. N., NASA $S P-106$, (1966).

(2) Hutton, R.E., NASA TND-1870, (1963).

(3) Miles, J. W., J. Fluid Mech., 149(1984), 1.

(4) Funakoshi, M. and Inoue, S., Fluid Dyna. Res., 5(1990), 255.
( 5 ) Benjamin, T. B. and Ursell, F., Proc. R. Soc., Ser. A, 225(1954), 505.

(6) Dodge, F. T., Kana, D. D. and Abramson, H. N., AIAA J., 3-4 (1965), 685.

（7）池田・秋山・中村・白井，土木学会論文報告集，290(1979), 53.

(8) Miles, J. W., J. Fluid Mech., 146(1984), 285.

（9）木村 - 高原 - 伊東 - 坂田, 機論, 58-556，C(1992)，3564.

（10）高原・木村・坂田，機論, 60-574, C (1994), 1924.

（11）高原 - 木村 - 坂田，機論，掲載決定 60-579, C (1994).

（12）坂田・木村・内海, 機論, 49-442, C (1983), 963. 